\begin{tabular}{lc}
\hline JOURNAL OF SCIENTIFIC PERSPECTIVES \\
RAADEMY \\
E-ISSN: $2587-3008$ \\
Attp://ratingacademy.com.tr/journals/index.php/jsp/ 2018, Vol:2, Issue: 2 \\
\hline
\end{tabular}

\title{
CYTOTOXIC AND MOLECULAR MECHANISMS IN OTOTOXICITY OF CISPLATIN
}

\author{
Assoc. Prof. Dr. Dilek Ülker ÇAKIR* \\ Canakkale Onsekiz Mart University, School of Medicine, Depatment of Biochemistry, Canakkale, \\ Turkey,E-mail: ducakir@comu.edu.tr \\ Prof. Dr. Zekiye ALTUN \\ Dokuz Eylül University, Oncology Institute, Department of Basic Oncology, İzmir, Turkey
}

Prof. Dr. Nur OLGUN

Dokuz Eylül University, Oncology Institute, Department of Basic Oncology, İzmir, Turkey

\begin{tabular}{l|l}
\hline \multicolumn{1}{c}{ ARTICLE INFO } & \multicolumn{1}{c}{ ABSTRACT } \\
\hline $\begin{array}{l}\text { Article History: } \\
\text { Received: } 23 \text { January } 2018 \\
\text { Accepted: } 30 \text { January } 2018\end{array}$ & $\begin{array}{l}\text { Ototoxicity is based on inner ear dysfunction creating hearing loss, balance } \\
\text { disorder or both symptoms depending on the drug or chemical agent. Genetic and } \\
\text { nongenetic risk factors, in addition to dose and time, play important roles in } \\
\text { cisplatin ototoxicity. Although the changes firstly begin from first line of outer } \\
\text { hairy cells on the Corti organ in the inner ear and then progress. Though the effect } \\
\text { on the spiral ganglion and stria vascularis in addition to the Corti organ are well- } \\
\text { defined, the molecular mechanisms that cause hearing loss are not fully } \\
\text { understood. Cellular and molecular mechanisms and particularly apoptotic } \\
\text { mechanisms explain cisplatin cytotoxicity leading to cochlea damage. DNA } \\
\text { cisplatin, } \text { cellutoxicity, } \\
\text { molecular, apoptotic } \\
\text { mechanisms. }\end{array}$ \\
$\begin{array}{l}\text { damage induced by cisplatin and ROS production seem to be mainly responsible } \\
\text { for cisplatin toxicity. } \\
\text { DOI: } 10.26900 / j s p .2018 .12\end{array}$ \\
$\begin{array}{l}\text { Children treated with cisplatin are at risk of early or late hearing loss which could } \\
\text { affect learning, communication, school performance, social communication and } \\
\text { general quality of life. For this reason, many protective agents are used with } \\
\text { cisplatin without changing its antitumoral efficiency. Studies of compounds to } \\
\text { prevent ototoxicity may provide compounds for use in routine clinical practice and } \\
\text { prevent one of the major dose-limiting side effects of cisplatin therapy, which will } \\
\text { increase treatment efficacy and improve patient quality of life. }\end{array}$
\end{tabular}

\section{INTRODUCTION}

A medication or chemical agent that causes inner ear dysfunction in the form of hearing loss, balance disorders or both symptoms together is said to cause ototoxicity. Ototoxicity occurs due to antibiotics, diuretics, anti-inflammatories, antimalarial medications, antineoplastic agents and some other medications.

The strong antineoplastic medication of cisplatin was first synthesized by Peyrone in 1845. In 1965 de Rosenberg and Cavalieri found platinum complexes that formed in the presence of ammonium and chloride ions. Cisplatin was used for clinical chemotherapy at the beginning of the 1970s as the most active platinum compound for experimental tumor systems (Rosenberg and Cavalieri 1965). Cisplatin (cis-diaminedichloroplatinum [II], CDDP) cisplatin (cis-diamminedichloroplatinum II) cisplatin (cis-diamminedichloroplatinum II) within the group called platinum compounds may be used in the treatment of many malignant diseases like head and neck squamous cell carcinoma, solid testis, ovarian, bladder, prostate, and cervix 
tumors and non-small cell lung carcinoma and for pediatric malignancies like neuroblastoma, osteosarcoma, hepatoblastoma and germ cell tumors (Ali et al. 2013, Gunes et al. 2009, Langer et al. 2013, Rybak et al. 2009, Rybak et al. 2007, Sakamoto et al. 2000, Waissbluth and Daniel 2013). Serious side effects limiting clinical use include nephrotoxicity and ototoxicity causing dose limitations. There are many studies on the side effects of cisplatin (Daldal et al. 2007, Fetoni et al. 2004a, Van den Berg et al. 2006).

\section{MATERIAL AND METHODS}

The ototoxic effect of cisplatin is characterized by temporary tinnitus accompanied by irreversible, progressive bilateral, moderate or severe sensorineural hearing loss beginning at high frequencies and then affecting low frequencies important for perception of speaking (Cooley et al. 1994, Fetoni et al. 2004a, Rybak et al. 2007, Sakamoto et al. 2000, Sluyter et al. 2003, Van den Berg et al. 2006). Ototoxicity is frequently associated with the dose and duration of cisplatin, while some genetic and non-genetic risk factors play a role in this irreversible side effect. Among non-genetic risk factors affecting the incidence of ototoxicity are form of use, cumulative dose, high cumulative dose ( $>400 \mathrm{mg} / \mathrm{m} 2)$, age (children younger than 5 years), bolus injections, dietary factors, malnutrition, anemia, hypoproteinemia, serum protein levels, use with medications that are ototoxic agents especially aminoglycosides, furosemide, gentamicin, amphotericin B and vancomycin, noise, low renal function, previous hearing loss and history of cranial radiotherapy (Cooley et al. 1994, Sakamoto et al. 2000). Severity of hearing loss is related to young age when cisplatin is first administered, number of cycles and high cumulative dose (Allen et al. 1998).

It is well known that as much as side effects, the pharmacological efficacy of a medication is linked to the intake, metabolism, excretion and detoxification of the medication. Genetic factors may affect the metabolic activity of medication. Coding isoenzymes playing a critical role in protection against ototoxicity in tumor cells and shown as a risk factor for cisplatin, five glutathione $S$ transferase (GST) genes were researched by Peters et al. (Peters et al. 2000) in a pharmacogenetic study in the pediatric population. Polymorphism was researched and it was found that GSTM3*B alelle had a protective effect against cisplatin ototoxicity. GST1, GSTT1 and GSTM1 gene polymorphisms are the most common abnormalities in ototoxicity formed by cisplatin. However, there are some debates related to the protective effect of GSTs linked to different tumor types, age, chemotherapy regimes, cumulative cisplatin doses, different analyses and statistical methods (Hirst and Robson 2010, Jamesdaniel et al. 2012b, Olgun et al. 2016a, Sanchez-Gonzalez et al. 2011, Tian et al. 2010, Wang et al. 2007). High megalin expression levels, expressed in marginal cells in the apical section of the inner ear stria vascularis, identified that single nucleotide polymorphisms (SNPs) rs2075252 and rs2228171 played a role in ototoxicity formed by cisplatin (Hirst and Robson 2010, Jamesdaniel et al. 2012b, Riedemann et al. 2008).

The use of chemotherapy combined with radiotherapy or radiotherapy combined with chemotherapy may be very effective on both the formation and degree of ototoxicity (Goldwein).

In spite of the histopathology of cisplatin ototoxicity being well-known, the hearing loss mechanism is not fully known. These mechanisms are still being defined in many studies (Cardinaal et al. 2000, Feghali et al. 2001, Hinojosa et al. 1995, Smoorenburg et al. 1999, Teranishi and Nakashima 2003, van Ruijven et al. 2005, van Ruijven et al. 2004). Ototoxicity has known cellular and molecular mechanisms. 


\section{Cellular mechanisms of ototoxicity}

Outer hair cell injury

Support cell injury

Nerve cell injury in the stria vascularis

Spiralligament injury

Spiralganglioncellinjury

\section{Molecular mechanisms of ototoxicity}

Formation of reactive oxygen species (ROS)

Loss of antioxidant glutathione and formative enzymes

Increased lipid peroxidation rates

Oxidative modifications of proteins

Nucleic acid damage with caspase system activation

S-nitrosylation of cochlear proteins

Changes in protein expression (Chirtes and Albu 2014)

\subsection{Cellular mechanisms of ototoxicity}

As soon as cisplatin enters cells it is transformed to a highly reactive intermediate product - monohydrate complexes (MHC) - which causes formation of reactive oxygen products and DNA damage resulting in apoptosis and cell death by an "aquation reaction" (intracellular hydrolytic biotransformation). MHC is believed to be the most important cytotoxic agent as it enters reactions with DNA (Deng et al. 2006). Additionally, it is believed that MHC is responsible for the basic toxic side effects of cisplatin (Deng et al. 2010).

Though cytotoxic effects ease the reduction in tumor size and/or prevent tumor development, they limit the anticancer efficacy of cisplatin and significantly limit the quality of life of people struggling with cancer.

Ototoxicity of cisplatin is characterized by cochlea injury (cochleotoxic) especially (Nakai et al. 1982). It affects three areas of the Corti organ in the inner ear (external hair cells), spiral ganglion cells and outer wall (stria vascularis and spiral ligament) (Langer et al. 2013). Cisplatin causes progressive injury to external hair cells in the cochlea, sporadic destruction of internal hair cells, atrophy of the stria vascularis, collapse of the Reissner membrane and damage to support cells in the Corti organ (Laurell and Bagger-Sjoback 1991) .

When used at low doses, initially it causes damage to stereocilia tip-link connections, this is later followed by stereocilia fusion and disorganization (Comis et al. 1986, Fetoni et al. 2004b). At high doses, it causes mitochondrial and endoplasma reticulum damage, loss of stereocilia and hair cells, atrophy of the stria vascularis, collapse of Reissner membrane and damage to support cells (Estrem et al. 1981, Fetoni et al. 2004b, Goncalves et al. 2013).

Hair cells are mechanotransducers in the inner ear necessary for hearing and balance. Hair cell death commonly occurs following exposure to acoustic trauma and to ototoxins like aminoglycoside antibiotics and the antineoplastic agent cisplatin. Loss causes permanent sensorineural hearing loss, balance disorder or both together. To aid in developing therapeutic 
strategies, it is necessary to better understand the molecular mechanisms underlying hair cell degeneration.

In response to cochlea trauma, hair cell death may occur through both necrosis and apoptosis routes. Apoptosis of hair cells is associated with caspases and secretion of inflammatory cytokines in response to trauma and MAPK/JNK pathways activated by oxidative stress. Description of pathways causing apoptosis provides therapeutic targets for protection of hearing (Abi-Hachem et al. 2010)

In the stria vascularis, reactive oxygen species (ROS) cause changes in permeability of the mitochondrial membrane and apoptosis of marginal cells. Degeneration of the stria vascularis is one of the first events in development of hearing loss due to cisplatin. Additionally, spiral ligament fibrocytes provide potassium $(\mathrm{K}+)$ for endolymph and thus keep the endolymph ionic concentration in balance with vital function for transformation of $\mathrm{K}+$. They have a bloodcochlear barrier function to prevent ototoxic medication effects. Degradation of these fibrocytes has been shown to be strongly linked to hearing loss (Le et al. 2017).

\subsection{Molecular mechanisms of ototoxicity}

Despite good descriptions of changes initially beginning with external hair cells of the Corti organ in the inner ear and then advancing to other areas, and affecting the spiral ganglion and stria vascularis in addition to the Corti, the molecular mechanisms underlying hearing loss are not fully understood (Jamesdaniel et al. 2012a, Karasawa and Steyger 2015, Kuhlmann et al. 1997, More et al. 2010, Rybak et al. 2007).

\section{CISPLATIN EXHAUSTS THE ANTIOXIDANT SYSTEM IN THE COCHLEA}

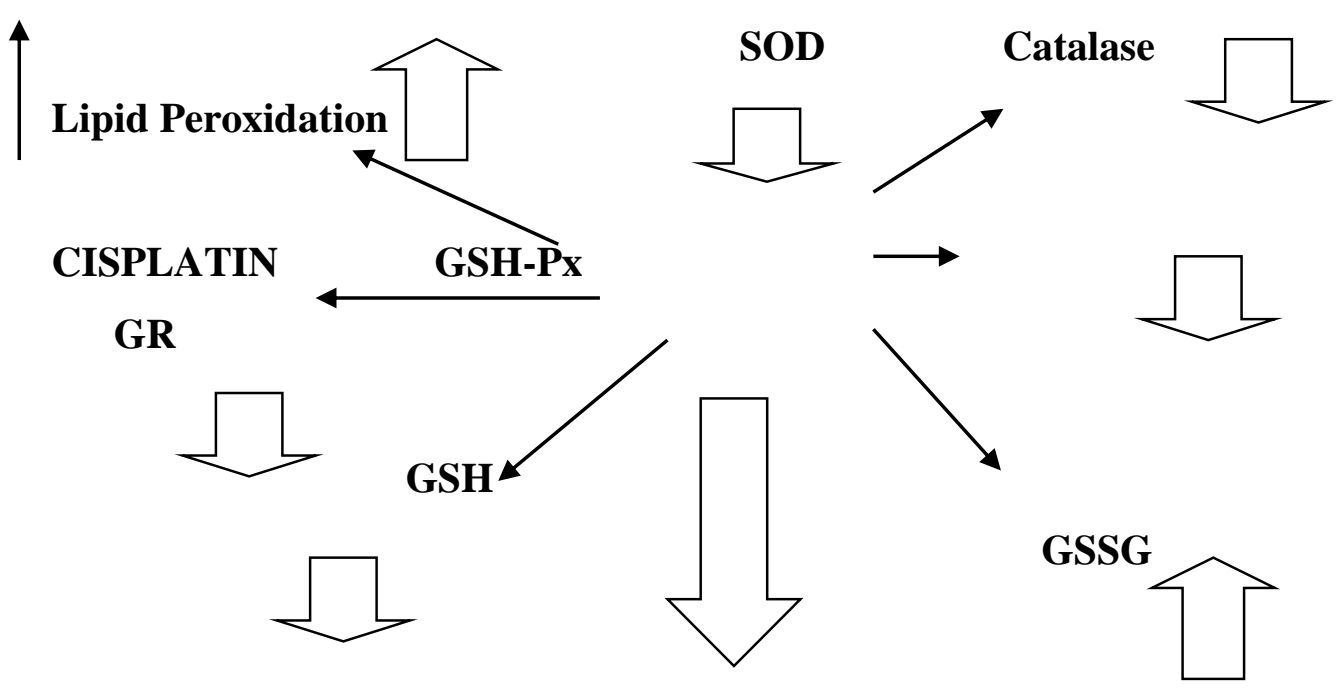

Figure 1. Effect of cisplatin on the antioxidant systems (Rybak et al. 2007)

Cisplatin and metabolites accumulate due to the cochlea being an anatomically closed system and metabolites being difficult to excrete (Ali et al. 2013, Deavall et al. 2012, Devarajan et al. 2002, Ding et al. 2012, Goncalves et al. 2013, Gunes et al. 2009, Langer et al. 2013, Rybak 2007, Rybak et al. 2009, Rybak et al. 2007, Sakamoto et al. 2000, Schacht et al. 2012, Waissbluth and Daniel 2013). The accumulating cisplatin is integrated into cellular DNA 
causing dysfunction of protein synthesis including antioxidant enzymes. The cochlea antioxidant systems include glutathione, glutathione peroxidase, glutathione reductase, superoxide dismutase, catalase, glutathione-S transferase and glutamyl cysteine synthetase (Waissbluth and Daniel 2013).Inhibition of antioxidant enzyme activities increases strong reactive oxygen species (ROS) responsible for ototoxicity of cisplatin like superoxide, hydrogen peroxide and hydroxyl radicals within the cochlea and allows the accumulation of toxic lipid peroxides (Clerici et al. 1995). Normally the cochlea has an endogenous antioxidant defense system related to the membrane scavenging ROS and preventing cell death caused by ROS. As a result of interaction of cellular components, the membranes experience damage such as aldehydic lipid peroxidation, oxidative modification of proteins and DNA lesions (Clerici et al. 1995, Giridharan et al. 2012, Ikeda et al. 1993, Mukhopadhyay et al. 2010, Raman et al. 2001).

In animals given ototoxic doses, malondialdehyde levels, an indicator of lipid peroxidation in cochlear tissues, showed reciprocal increase with a reduction observed in glutathione and antioxidant enzyme levels (Banfi et al. 2004, Clerici et al. 1995, Clerici and Yang 1996, Dehne et al. 2001, Kopke et al. 1997, Rybak et al. 2000). Lipid peroxidation in cochlear tissues may result in disrupted activities of antioxidant enzymes and glutathione reductase as much as a reduction in glutathione. The reduction in cochlear antioxidant enzyme activities may be linked to direct bonding of sulfhydryl groups in enzymes to cisplatin reduction in copper and selenium important for superoxide dismutase and glutathione peroxidase activities (DeWoskin and Riviere 1992) increased inactivation of organic peroxides by ROS and antioxidant enzymes (Pigeolet et al. 1990) reduction in NAPDH and glutathione (Somani et al. 2001) necessary for glutathione peroxidase and glutathione reductase activities (Fechter and Pouyatos 2005, Fetoni et al. 2004b, Teranishi and Nakashima 2003, Van den Berg et al. 2006) .

Reactive oxygen species molecularly activate signal transducer and activator of transcription (STAT1) transcription factor beginning inflammatory and apoptotic cascades in the cochlea (Avan et al. 2015, Jamesdaniel et al. 2008, Kaur et al. 2016). Reactive nitrogen species contribute to cisplatin ototoxicity (Giridharan et al. 2012, Manetopoulos et al. 2003) .

Superoxide radicals formed from hydroxyl radicals $(\mathrm{OH}-)$ react with unsaturated fat acids in the lipid layer of the cell membrane causing formation of the very toxic aldehyde 4hydroxynonenal. The increase in aldehyde 4-hydroxynonenal causes increased calcium flow in external hair cells and apoptosis (Sanchez-Gonzalez et al. 2011)It may inactivate antioxidant enzymes and cause release of cytochrome $\mathrm{C}$ from damaged mitochondria and then caspase 9, 3 and 7 activation leading to migration of pro-apoptotic Bax protein to the cytosol.

The free radical of NO (nitric oxide) is formed by the nitric oxide synthase (NOS) enzyme in cells. NO production is linked to $\mathrm{Ca}^{2+} / \mathrm{CaM}$ bonding and has broad distribution in cochlear cells (Fessenden et al. 1994, Hess et al. 1999). One of the 3 isoforms of NOS described in mammals of nNOS plays a specific role in hair cell physiology (Zdanski et al. 1998) and eNOS is responsible for regulation of cochlear blood flow (Ren et al. 1997). Under normal conditions, iNOS is inactive or not expressed in the cochlea (Gosepath et al. 1997, Hess et al. 1999) and controls transcriptional levels and this isoform produces high rates of NO. NO is a very important gas structure material for hearing function (Fessenden et al. 1994, Gosepath et al. 1997, Hess et al. 1999). The effects of NO are essential for physiologic functions; however, as NO is a free radical excessive production is damaging for cochlear tissues (Raman et al. 2001, Takumida and Anniko 2001, Watanabe et al. 2001, Watanabe et al. 2000).

The 3 isoforms of the nicotinamide adenine dinucleotide phosphate oxidase enzyme (NOX3) (NOX3NAPDH oxidase pathway) only found in the inner ear contribute significantly 
to ROS formation and are thought to play a clear role in cochlear oxidation (Watanabe et al. 2001, Watanabe et al. 2000). In cochlear tissue increased ROS causes peroxynitrite formation which enters reactions with nitric oxide (Kaur et al. 2016) ROS in cochlear tissue may increase expression of transient vanilloid receptor potential 1 ion channel (receptor transient potential V1), a member of the transient receptor family of ion channel proteins and expressed by smalldiameter neurons and non-neuronal tissues (Corti) (Tian et al. 2010, Wang et al. 2007) This increase leads to calcium loading and increased calcium flow to cells contributing to apoptosis and cell death by caspase activation (Deng et al. 2006, Ross et al. 1983, Watanabe et al. 2001).

\subsection{Apoptotic mechanism of cisplatin toxicity}

Apoptotic cell death forms the basis of understanding cisplatin toxicity in healthy tissues like the cochlea (Biedler et al. 1978, Bollimuntha et al. 2005, Cheng et al. 2005). Apoptotic cell death is linked to the formation of ROS in the cochlea. Additionally, oxidative stress induced by the medication may trigger a cascade of intracellular reactions leading to apoptosis.

The first mechanism proposed for the cytotoxic mechanism of cisplatin is that it affects nucleophilic structures like guanine and adenine (complex interactions between cisplatin and damaged DNA) (Rausaria et al. 2011). Cisplatin binds covalently to guanine bases in DNA, inducing p53 by inter chain and intrachain crosslink formations, with aberrant genetic transcription preventing normal cell cycle progression and causing cell cycle arrest and apoptosis (Laurell and Bagger-Sjoback 1991). The 2nd proposed mechanism attracts attention to the much-more debated free radical formation and increased ROS (Teranishi and Nakashima 2003). Apart from this, cisplatin ototoxicity is associated with mitochondrial dysfunction (Fechter and Pouyatos 2005). and increased RNS (reactive nitrogen species) (Fetoni et al. 2004b) (37) formation. Reactive oxygen species (ROS) increase lipid peroxidation, change enzyme and structural proteins and cause apoptotic cell death. The medication induced oxidative stress may trigger an intracellular reaction cascade leading to apoptosis (Goncalves et al. 2013).

Studies in recent times have illuminated the roles of molecules containing and affecting the flows of MAPK (mitogen activated protein kinases) and p53. They may trigger mitochondrial pathway mediated apoptotic cascades (Ali et al. 2013, Gunes et al. 2009, Langer et al. 2013, Rybak et al. 2009, Rybak et al. 2007). With the reduction in antioxidant enzymes, increased aldehydes and total lipid peroxidases like malondialdehyde, aldehyde 4hydroxynonenal and peroxynitrite increase calcium influx to cochlear cells and release of cytochrome c from mitochondria and caspase 9 and caspase 3 activation causes apoptosis (Ali et al. 2013, Deavall et al. 2012, Devarajan et al. 2002, Ding et al. 2012, Goncalves et al. 2013, Gunes et al. 2009, Langer et al. 2013, Rybak 2007, Rybak et al. 2009, Rybak et al. 2007, Sakamoto et al. 2000, Schacht et al. 2012, Waissbluth and Daniel 2013).In response to different ototoxic stimuli, degeneration mechanisms of sensory hair cells generally unite in a single route; caspase activation. The key molecules in the hair cell death mechanism are caspase- 9 and -3 . The Bcl-2 family is a group of proapoptotic and antiapoptotic molecules regulating caspase activation and flows. Caspase inhibition prevents or delays hair cell death and may protect hearing/balance functions (Cheng et al. 2005). 


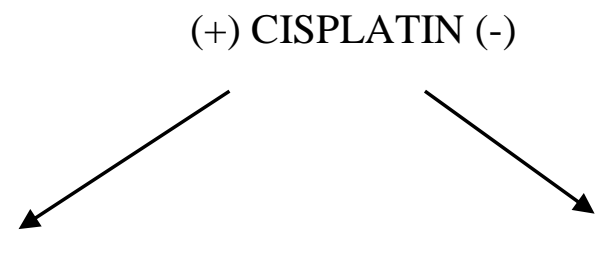

Lipid peroxidation products

Glutathione\&Antioxidant systems
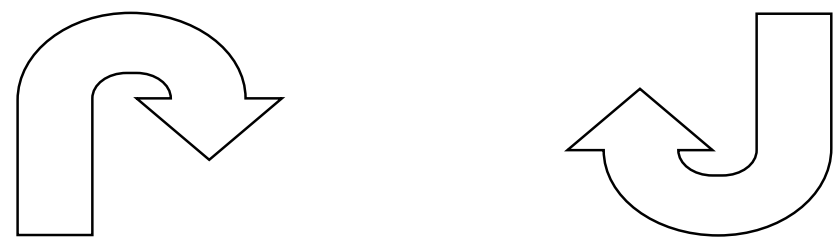

Cell death pathways

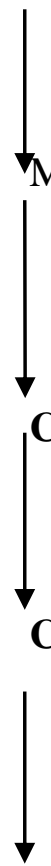

\section{Caspase 3}

Figure 2. Apoptotic Mechanism of cisplatin toxicity

In short, the apoptotic process encompasses disrupted redox status, increased lipid peroxidation, formation of DNA products and increased production of proinflammatory cytokines (Kim et al. 2014). The role of cytokines in cytotoxicity of cisplatin has been shown by many studies. At cellular level, cisplatin ototoxicity includes a network of complex events including ROS formation, and activation of inflammatory cytokines and stress signal pathways. These events cause cell death due to apoptosis (Boulikas and Vougiouka 2003, Rybak et al. 2007). Apoptotic cell death is reported to form by expression and secretion of proinflammatory cytokines via ERK and NF-KB activation. In HEI-OC1 cells treated with cisplatin, it is noteworthy that there is an increase shown for proinflammatory cytokines of TNF- $\alpha$, IL-1 $\beta$, and IL-6with increased activation of MAPKS and NF-kB (Boulikas and Vougiouka 2003, Kim et al. 2014) . 
As seen in apoptosis created by cisplatin, there are a variety of signal pathways. Definition of the signal pathways regulating the cytotoxic effects of cisplatin is necessary to discover targets that may be manipulated to prevent side effects among people fighting cancer.

Nitrosative stress-sensitive cells were revealed as an important factor affecting apoptotic signalization (Hirst and Robson 2010). Nitration and nitrosylation of proteins induced by cisplatin has been shown in the cochlea. Nitratified proteins are known cells targeted by cisplatin, but are especially localized in external hair cells (Jamesdaniel et al. 2012a, Jamesdaniel et al. 2012b).Increased nitrogen and nitrite levels (Giridharan et al. 2012, Jamesdaniel et al. 2008, Mukhopadhyay et al. 2010) regulate phosphorylation cascades in protein nitration, easing proteolytic degradation of nitratified proteins and disrupting protein functions and may cause vital changes in cell biological functions.

Behaving as a scaffold protein (Manetopoulos et al. 2003, Sum et al. 2002) and binding with many transcription factors to regulate signal formation as transcriptional regulator is necessary for normal development in both the cochlea and vestibule (Deng et al. 2006, Deng et al. 2010). LMO4 is defined as the most nitratified cochlear protein in ototoxicity induced by cisplatin (Le et al. 2017) (Jamesdaniel et al. 2012a)). In Wistar rat studies of LMO4 and the study by Rajamani et al. it was identified to play a role in easing the occurrence of ototoxic side effects of cisplatin (Jamesdaniel et al. 2012a) . There are studies explaining the regulation of cellular apoptosis with LMO4 (Tian et al. 2010, Wang et al. 2007) . Reduction in LMO4 inhibits epithelial cell proliferation and the increase is a toxic side effect of cisplatin. It was shown to play a potential role in easing cell death and apoptotic responses. Targeted inhibition of LMO4 nitration and/or LMO4 degradation in sensitive cells may be a potential therapeutic strategy to prevent side effects of cisplatin (Rathinam et al. 2015) .

While procedures including high energy radiation and especially doses above $>30$ Gy for pediatric head and neck tumors, especially, and neuroblastoma, hepatoblastoma, osteosarcoma or germ cell tumors affect the ear, commonly used radiotherapy platinum compounds (cisplatin and/or carboplatin) alone or in combination create significant risks for patients. Hearing loss in children may be more severe as radiotherapy is used more often for head/neck solid tumors compared to adults. Standard therapy for head/neck cancers is CRT (concurrent chemoradiotherapy) (El-Sayed and Nelson 1996, Munro 1995, Pignon et al. 2005, Pignon et al. 2000, Pignon et al. 2007). Ototoxic effects generally occur on the second day after the start of treatment and may continue until seven days after treatment ceases (Cooley et al. 1994, Feghali et al. 2001, Janning et al. 1998, Rybak et al. 2007, Sakamoto et al. 2000, van Ruijven et al. 2005) The threshold value for hearing loss in patients receiving combined radiotherapy and chemotherapy treatment is 10 Gy (Hitchcock et al. 2009) At doses lower than 40 Gy, patients receiving radiotherapy for head-neck cancers will not have clinically significant hearing loss. However, when patients also receive $100 \mathrm{mg} / \mathrm{m}^{2}$ cisplatin, sensorineural hearing loss is high. Cranial radiation increases the possibility and severity of hearing loss (Hitchcock et al. 2009). With density-regulated radiotherapy, some authors have found administration of limited radiation into the inner or middle ear may protect hearing (Plowman 2002). Additionally, as the inner ear is included in the irradiation area, there is more danger of permanent sensorineural hearing loss as a result of radiotherapy including the cochlea. Sensorineural hearing loss forms after a latent period varying from 1.5 years to 5 years after conventional fractionated radiotherapy (Arora et al. 2009, Hua et al. 2008, Jereczek-Fossa et al. 2003, Low et al. 2006, Paulino et al. 2000, Pearson et al. 2006, Wang et al. 2004, Zhang et al. 2009).

This type of reduction in hearing appears to result in loss of cilia cells especially in the basal section and/or spiral ganglion damage in the cochlea. The etiology of these losses is thought to be related to insufficient vascularization, fibrosis and ossification of inner ear fluids (Chen et al. 1999, Zuur et al. 2009) causing atrophy and progressive degeneration of inner ear 
sensory structures and abnormalities of the cochlear nerve. Hearing difficulties create negative effects and cause limitations or changes affecting the lives of cancer patients. Chen et al. (Chen et al. 1999) accepted that radiation doses higher than $6000 \mathrm{cGy}$ was the most significant factor for the presence of sensorineural hearing loss. A study by Herman et al. (Herrmann et al. 2006) with 2000-3000 cGy doses to the cochlea found clear hearing loss in 50\% of patients and ototoxic effects formed after radiotherapy $41.8 \%$ of patients with head and neck tumors. Bhandare et al. (Bhandare et al. 2007, Schultz et al. 2010) attributed complications to the dose of radiotherapy. The authors stated the incidence of ototoxic effects increased when the radiotherapy doses increased from 6000 to $6600 \mathrm{cGy}$. This study found a total dose of 6500 cGy was statistically significant for the presence of hearing loss.

Children treated with platinum compounds, especially cisplatin, are at risk of early or late hearing loss which may affect learning, communication, school performance, social communication and general quality of life. For this reason, many protective agents that do not change the antitumoral efficacy but reduce the injury caused by cisplatin are used together with cisplatin. Glucocorticoids (dexamethasone, prednisone, methylprednisolone, etc.) and vitamin $\mathrm{E}$ are promising potential medication groups for otoprotection(Cooley et al. 1994) . Corticosteroids have been shown to limit ROS formation in the inner ear (Fechter and Pouyatos 2005, Goncalves et al. 2013, Laurell and Bagger-Sjoback 1991).

Vitamin E is a vitamin including tocopherol and tocotrienol species. Due to the lipophilic property of $\alpha$-tocopherol with highest antioxidant activity, it is a membrane-specific antioxidant forming the first line of defense for unsaturated fat acids in the structure of membranal phospholipids from the effect of free radicals. The lipid peroxyl radical is removed and the lipid peroxidation chain reactions end. Due to this property, it is known as the chain-breaking antioxidant (Rybak 2007, Rybak et al. 2007, Waissbluth and Daniel 2013) Teranishi and Fetoni et al. (Fetoni et al. 2004b, Teranishi and Nakashima 2003) showed that vitamin E has a protective effect against the ototoxicity of cisplatin (Rybak 2007, Rybak et al. 2007, Waissbluth and Daniel 2013) .

There are strong nucleophilic compounds containing sulfur that have the ability to enter interactions with the electrophilic structure of platinum linked to large density of electrons around the sulfur atoms. Amifostine, WR-1065, N-acetyl cysteine, acetyl-1-carnitine, dmethionine, sodium thiosulfate and erdostein thio are among these protective agents as they form complexes with cisplatin due to structure (Altun et al. 2014, Altun et al. 2016, Altun et al. 2010, Gunes et al. 2011, Olgun et al. 2013, Olgun et al. 2014, Tufekci et al. 2009) (Altun et al. 2014, Altun et al. 2016, Altun et al. 2010, Doğan et al. 2014, Gunes et al. 2011, Olgun et al. 2013, Olgun et al. 2016b, Olgun et al. 2014, Tufekci et al. 2009). As ROS formation is the most important factor starting ototoxicity, strategies to prevent ototoxicity include administering free radical scavengers (amifostine, acetyl cysteine, salicylate and vitamin E) to prevent ROS reactions with cellular protein, lipid and DNA. Other strategies include administering compounds that can induce endogenous antioxidant production (acetyl cysteine, sodium thiosulfate, salicylate, d-methionine and ebselen) and agents that prevent ROS formation (allopurinol, erdosteine and adenosine agonists).

Many experimental studies have reported a variety of compounds like acetyl-L-carnitine (Altun et al. 2014, Altun et al. 2016, Altun et al. 2010, Gunes et al. 2011, Tufekci et al. 2009), resveratrol (Olgun et al. 2013, Olgun et al. 2014) Korean red ginseng (Olgun et al. 2016b) and recombinant human erythropoietin(Doğan et al. 2014) with significant chemoprotective effects on ototoxicity after administration of cisplatin. 


\section{CONCLUSION}

The main factors responsible for toxicity of cisplatin are the induced DNA damage and ROS production. A variety of clinical approaches have been developed to prevent or reduce these effects. In light of results obtained from studies of compounds to reduce ototoxicity, there is no specific agent that can be transferred to routine clinical practice. In addition to the lack of consensus about agents that may be used for otoprotective aims, there is no definite consensus of the administration route for these agents. Today these results are carried to clinical practice by important animal models. The use of stem cells to repair cells and organs that do not have the ability to regenerate is hopeful for ototoxicity. In clinical practice the greatest potential is for amifostine, vitamin E, silymarin and NK-1 receptor agonists (Santabarbara et al. 2016).

One of these studied compounds may have protective ability against ototoxicity and thus may resolve one of the major dose-limiting side effects of cisplatin therapy. Possibly this will increase the efficacy of cisplatin treatment and improve the quality of life of a broad group of patients. 


\section{REFERENCES}

ABI-HACHEM, R.N., ZINE, A., VAN DE WATER, T.R., 2010, The injured cochlea as a target for inflammatory processes, initiation of cell death pathways and application of related otoprotectives strategies, Recent Pat CNS Drug Discov, 5(2):147-163.

ALI, I., WANI, W.A., SALEEM, K., HAQUE, A., 2013, Platinum compounds: a hope for future cancer chemotherapy, Anticancer Agents Med Chem, 13(2):296-306.

ALLEN, G.C., TIU, C., KOIKE, K., RITCHEY, A.K., KURS-LASKY, M., WAX, M.K., 1998, Transient-evoked otoacoustic emissions in children after cisplatin chemotherapy, Otolaryngol Head Neck Surg, 118(5):584-588.

ALTUN, Z., OLGUN, Y., ERCETIN, P., AKTAS, S., KIRKIM, G., SERBETCIOGLU, B., OLGUN, N., GUNERI, E.A., 2014, Protective effect of acetyl-l-carnitine against cisplatin ototoxicity: role of apoptosis-related genes and pro-inflammatory cytokines, Cell Prolif, 47(1):72-80.

ALTUN, Z., PAMUKOĞLU, A., OLGUN, Y., AKTAŞ, S., ÇETINAYAK, H.O., KıRKı1M, G., GÜNERI, E.A., ERÇETIN, P., OLGUN, N., 2016, Acetyl-L-Carnitine protects HEIOC1 auditory cells from radiation and cisplatin induced toxicity, Int J Clin Exp Med, 9(7):13605-13614.

ALTUN, Z.S., GUNES, D., AKTAS, S., ERBAYRAKTAR, Z., OLGUN, N., 2010, Protective effects of Acetyl-L-carnitine on cisplatin cytotoxicity and oxidative stress in neuroblastoma, Neurochem Res, 35(3):437-443.

ARORA, R., THAKUR, J.S., AZAD, R.K., MOHINDROO, N.K., SHARMA, D.R., SEAM, R.K., 2009, Cisplatin-based chemotherapy: Add high-frequency audiometry in the regimen, Indian J Cancer, 46(4):311-317.

AVAn, A., POStMA, T.J., CERESA, C., CAVAletti, G., GiOVANNETTI, E., PETERS, G.J., 2015, Platinum-induced neurotoxicity and preventive strategies: past, present, and future, Oncologist, 20(4):411-432.

BANFI, B., MALGRANGE, B., KNISZ, J., STEGER, K., DUBOIS-DAUPHIN, M., KRAUSE, K.-H., 2004, NOX3, a superoxide-generating NADPH oxidase of the inner ear, Journal of Biological Chemistry, 279(44):46065-46072.

BAYRAK, F., OLGUN, Y., ALTUN, Z., Ototoksisite ve Kök Hücre Uygulamaları, İzmir Eğitim ve Araştırma Hastanesi Tıp Dergisi:47.

BHANDARE, N., ANTONELLI, P.J., MORRIS, C.G., MALAYAPA, R.S., MENDENHALL, W.M., 2007, Ototoxicity after radiotherapy for head and neck tumors, Int J Radiat Oncol Biol Phys, 67(2):469-479.

BIEDLER, J.L., ROFFLER-TARLOV, S., SCHACHNER, M., FREEDMAN, L.S., 1978, Multiple neurotransmitter synthesis by human neuroblastoma cell lines and clones, Cancer Res, 38(11 Pt 1):3751-3757.

BOLlimunTHA, S., SINGH, B.B., SHAVAli, S., SHARMA, S.K., EBADI, M., 2005, TRPC1-mediated inhibition of 1-methyl-4-phenylpyridinium ion neurotoxicity in human SH-SY5Y neuroblastoma cells, J Biol Chem, 280(3):2132-2140.

BOULIKAS, T., VOUGIOUKA, M., 2003, Cisplatin and platinum drugs at the molecular level. (Review), Oncol Rep, 10 (6):1663-1682.

CARDINAAL, R.M., DE GROOT, J.C., HUIZING, E.H., VELDMAN, J.E., SMOORENBURG, G.F., 2000, Cisplatin-induced ototoxicity: morphological evidence 
of spontaneous outer hair cell recovery in albino guinea pigs?, Hear Res, 144(1-2):147156.

CHEN, W.C., LIAO, C.T., TSAI, H.C., YEH, J.Y., WANG, C.C., TANG, S.G., HONG, J.H., 1999, Radiation-induced hearing impairment in patients treated for malignant parotid tumor, Ann Otol Rhinol Laryngol, 108(12):1159-1164.

CHENG, A.G., CUNNINGHAM, L.L., RUBEL, E.W., 2005, Mechanisms of hair cell death and protection, Curr Opin Otolaryngol Head Neck Surg, 13(6):343-348.

CHIRTES, F., ALBU, S., 2014, Prevention and restoration of hearing loss associated with the use of cisplatin, Biomed Res Int, 2014:925485.

CLERICI, W.J., DIMARTINO, D.L., PRASAD, M.R., 1995, Direct effects of reactive oxygen species on cochlear outer hair cell shape in vitro, Hear Res, 84(1-2):30-40.

CLERICI, W.J., YANG, L., 1996, Direct effects of intraperilymphatic reactive oxygen species generation on cochlear function, Hear Res, 101(1-2):14-22.

COMIS, S.D., RHYS-EVANS, P.H., OSBORNE, M.P., PICKLES, J.O., JEFFRIES, D.J., PEARSE, H.A., 1986, Early morphological and chemical changes induced by cisplatin in the guinea pig organ of Corti, J Laryngol Otol, 100(12):1375-1383.

COOLEY, M.E., DAVIS, L., ABRAHM, J., 1994, Cisplatin: a clinical review. Part II--Nursing assessment and management of side effects of cisplatin, Cancer Nurs, 17(4):283-293.

DALDAL, A., ODABASI, O., SERBETCIOGLU, B., 2007, The protective effect of intratympanic dexamethasone on cisplatin-induced ototoxicity in guinea pigs, Otolaryngol Head Neck Surg, 137(5):747-752.

DEAVALL, D.G., MARTIN, E.A., HORNER, J.M., ROBERTS, R., 2012, Drug-induced oxidative stress and toxicity, J Toxicol, 2012:645460.

DEHNE, N., LAUTERMANN, J., PETRAT, F., RAUEN, U., DE GROOT, H., 2001, Cisplatin ototoxicity: involvement of iron and enhanced formation of superoxide anion radicals, Toxicol Appl Pharmacol, 174(1):27-34.

DENG, M., PAN, L., XIE, X., GAN, L., 2006, Differential expression of LIM domain-only (LMO) genes in the developing mouse inner ear, Gene Expr Patterns, 6(8):857-863.

DENG, M., PAN, L., XIE, X., GAN, L., 2010, Requirement for Lmo4 in the vestibular morphogenesis of mouse inner ear, Dev Biol, 338(1):38-49.

DEVARAJAN, P., SAVOCA, M., CASTANEDA, M.P., PARK, M.S., ESTEBANCRUCIANI, N., KALINEC, G., KALINEC, F., 2002, Cisplatin-induced apoptosis in auditory cells: role of death receptor and mitochondrial pathways, Hear Res, 174(12):45-54.

DEWOSKIN, R.S., RIVIERE, J.E., 1992, Cisplatin-induced loss of kidney copper and nephrotoxicity is ameliorated by single dose diethyldithiocarbamate, but not mesna, Toxicol Appl Pharmacol, 112(2):182-189.

DING, D., ALLMAN, B.L., SALVI, R., 2012, Review: ototoxic characteristics of platinum antitumor drugs, Anat Rec (Hoboken), 295(11):1851-1867.

DOĞAN, E., OLGUN, Y., KıRKı1M, G., KOLATAN, E., ERÇETIN, P., AKTAŞ, S., ALTUN, Z., ELLIDOKUZ, H., KIRAY, M., BAĞRIYAI1K, A., 2014, The Protective Effect of Recombinant Human Erythropoietin against Cisplatin-Induced Ototoxicity, Journal of International Advanced Otology, 10(3). 
EL-SAYED, S., NELSON, N., 1996, Adjuvant and adjunctive chemotherapy in the management of squamous cell carcinoma of the head and neck region. A meta-analysis of prospective and randomized trials, J Clin Oncol, 14(3):838-847.

ESTREM, S.A., BABIN, R.W., RYU, J.H., MOORE, K.C., 1981, Cisdiamminedichloroplatinum (II) ototoxicity in the guinea pig, Otolaryngol Head Neck Surg, 89(4):638-645.

FECHTER, L.D., POUYATOS, B., 2005, Ototoxicity, Environ Health Perspect, 113(7): A443444.

FEGHALI, J.G., LIU, W., VAN DE WATER, T.R., 2001, L-N-Acetyl-Cysteine Protection Against Cisplatin-Induced Auditory Neuronal and Hair Cell Toxicity, The Laryngoscope, 111(7):1147-1155.

FESSENDEN, J.D., COLING, D.E., SCHACHT, J., 1994, Detection and characterization of nitric oxide synthase in the mammalian cochlea, Brain Res, 668(1-2):9-15.

FETONI, A.R., QUARANTA, N., MARCHESE, R., CADONI, G., PALUDETTI, G., SERGI, B., 2004a, The protective role of tiopronin in cisplatin ototoxicity in Wistar rats, Int $\mathbf{J}$ Audiol, 43(8):465-470.

FETONI, A.R., SERGI, B., FERRARESI, A., PALUDETTI, G., TROIANI, D., 2004b, Protective effects of alpha-tocopherol and tiopronin against cisplatin-induced ototoxicity, Acta Otolaryngol, 124(4):421-426.

GIRIDHARAN, V.V., THANDAVARAYAN, R.A., BHILWADE, H.N., KO, K.M., WATANABE, K., KONISHI, T., 2012, Schisandrin B, attenuates cisplatin-induced oxidative stress, genotoxicity and neurotoxicity through modulating NF-kappaB pathway in mice, Free Radic Res, 46(1):50-60.

GOLDWEIN, J., Late radiation-associated deafness in children treated for medulloblastoma and brainstem tumors, a newly recognized sequelae of radiation treatment. Oncolink website, University of Pennsylvania, Oncolink website, University of Pennsylvania.

GONCALVES, M.S., SILVEIRA, A.F., TEIXEIRA, A.R., HYPPOLITO, M.A., 2013, Mechanisms of cisplatin ototoxicity: theoretical review, J Laryngol Otol, 127(6):536541.

GOSEPATH, K., GATH, I., MAURER, J., POLLOCK, J.S., AMEDEE, R., FORSTERMANN, U., MANN, W., 1997, Characterization of nitric oxide synthase isoforms expressed in different structures of the guinea pig cochlea, Brain Res, 747(1):26-33.

GUNES, D., KIRKIM, G., DEMIRAL, P., UYSAL, K.M., SERBETCIOGLU, B., OLGUN, N., 2009, Platinum-induced ototoxicity in children and adolescents with cancer, J Int Adv Otol, 5:345-355.

GUNES, D., KIRKIM, G., KOLATAN, E., GUNERI, E.A., OZOGUL, C., ALTUN, Z., SERBETCIOGLU, B., YILMAZ, O., AKTAS, S., MUTAFOGLU, K., TUFEKCI, O., ERBAYRAKTAR, Z., OLGUN, N., 2011, Evaluation of the effect of acetyl L-carnitine on experimental cisplatin ototoxicity and neurotoxicity, Chemotherapy, 57(3):186-194.

HERRMANN, F., DORR, W., MULLER, R., HERRMANN, T., 2006, A prospective study on radiation-induced changes in hearing function, Int $\mathrm{J}$ Radiat Oncol Biol Phys, 65(5):1338-1344.

HESS, A., BLOCH, W., HUVERSTUHL, J., SU, J., STENNERT, E., ADDICKS, K., MICHEL, O., 1999, Expression of inducible nitric oxide synthase (iNOS/NOS II) in the 
cochlea of guinea pigs after intratympanical endotoxin-treatment, Brain Res, 830(1):113-122.

HINOJOSA, R., RIGGS, L.C., STRAUSS, M., MATZ, G.J., 1995, Temporal bone histopathology of cisplatin ototoxicity, Am J Otol, 16(6):731-740.

HIRST, D.G., ROBSON, T., 2010, Nitrosative stress as a mediator of apoptosis: implications for cancer therapy, Curr Pharm Des, 16(1):45-55.

HITCHCOCK, Y.J., TWARD, J.D., SZABO, A., BENTZ, B.G., SHRIEVE, D.C., 2009, Relative contributions of radiation and cisplatin-based chemotherapy to sensorineural hearing loss in head-and-neck cancer patients, Int J Radiat Oncol Biol Phys, 73(3):779788 .

HUA, C., BASS, J.K., KHAN, R., KUN, L.E., MERCHANT, T.E., 2008, Hearing loss after radiotherapy for pediatric brain tumors: effect of cochlear dose, Int J Radiat Oncol Biol Phys, 72(3):892-899.

IKEDA, K., SUNOSE, H., TAKASAKA, T., 1993, Effects of free radicals on the intracellular calcium concentration in the isolated outer hair cell of the guinea pig cochlea, Acta Otolaryngol, 113(2):137-141.

JAMESDANIEL, S., COLING, D., HINDUJA, S., DING, D., LI, J., CASSIDY, L., SEIGEL, G.M., QU, J., SALVI, R., 2012a, Cisplatin-induced ototoxicity is mediated by nitroxidative modification of cochlear proteins characterized by nitration of Lmo4, J Biol Chem, 287(22):18674-18686.

JAMESDANIEL, S., DING, D., KERMANY, M.H., DAVIDSON, B.A., KNIGHT, P.R., 3RD, SALVI, R., COLING, D.E., 2008, Proteomic analysis of the balance between survival and cell death responses in cisplatin-mediated ototoxicity, J Proteome Res, 7(8):35163524.

JAMESDANIEL, S., MANOHAR, S., HINDUJA, S., 2012b, Is S-nitrosylation of cochlear proteins a critical factor in cisplatin-induced ototoxicity?, Antioxid Redox Signal, 17(7):929-933.

JANNING, M.H., WHITWORTH, C.A., RYBAK, L.P., 1998, Experimental model of cisplatin ototoxicity in chinchillas, Otolaryngol Head Neck Surg, 119(6):574-580.

JERECZEK-FOSSA, B.A., ZAROWSKI, A., MILANI, F., ORECCHIA, R., 2003, Radiotherapy-induced ear toxicity, Cancer Treat Rev, 29(5):417-430.

KARASAWA, T., STEYGER, P.S., 2015, An integrated view of cisplatin-induced nephrotoxicity and ototoxicity, Toxicol Lett, 237(3):219-227.

KAUR, T., BORSE, V., SHETH, S., SHEEHAN, K., GHOSH, S., TUPAL, S., JAJOO, S., MUKHERJEA, D., RYBAK, L.P., RAMKUMAR, V., 2016, Adenosine A1 Receptor Protects Against Cisplatin Ototoxicity by Suppressing the NOX3/STAT1 Inflammatory Pathway in the Cochlea, J Neurosci, 36(14):3962-3977.

KIM, J., CHO, H.J., SAGONG, B., KIM, S.J., LEE, J.T., SO, H.S., LEE, I.K., KIM, U.K., LEE, K.Y., CHOO, Y.S., 2014, Alpha-lipoic acid protects against cisplatin-induced ototoxicity via the regulation of MAPKs and proinflammatory cytokines, Biochem Biophys Res Commun, 449(2):183-189.

KOPKE, R.D., LIU, W., GABAIZADEH, R., JACONO, A., FEGHALI, J., SPRAY, D., GARCIA, P., STEINMAN, H., MALGRANGE, B., RUBEN, R.J., RYBAK, L., VAN DE WATER, T.R., 1997, Use of organotypic cultures of Corti's organ to study the 
protective effects of antioxidant molecules on cisplatin-induced damage of auditory hair cells, Am J Otol, 18(5):559-571.

KUHLMANN, M.K., BURKHARDT, G., KOHLER, H., 1997, Insights into potential cellular mechanisms of cisplatin nephrotoxicity and their clinical application, Nephrol Dial Transplant, 12(12):2478-2480.

LANGER, T., AM ZEHNHOFF-DINNESEN, A., RADTKE, S., MEITERT, J., ZOLK, O., 2013, Understanding platinum-induced ototoxicity, Trends Pharmacol Sci, 34(8):458469.

LAURELL, G., BAGGER-SJOBACK, D., 1991, Dose-dependent inner ear changes after i.v. administration of cisplatin, J Otolaryngol, 20(3):158-167.

LE, Q., TABUCHI, K., WARABI, E., HARA, A., 2017, The role of peroxiredoxin I in cisplatininduced ototoxicity, Auris Nasus Larynx, 44(2):205-212.

LOW, W.K., TOH, S.T., WEE, J., FOOK-CHONG, S.M., WANG, D.Y., 2006, Sensorineural hearing loss after radiotherapy and chemoradiotherapy: a single, blinded, randomized study, J Clin Oncol, 24(12):1904-1909.

MANETOPOULOS, C., HANSSON, A., KARLSSON, J., JONSSON, J.I., AXELSON, H., 2003, The LIM-only protein LMO4 modulates the transcriptional activity of HEN1, Biochem Biophys Res Commun, 307(4):891-899.

MORE, S.S., AKIL, O., IANCULESCU, A.G., GEIER, E.G., LUSTIG, L.R., GIACOMINI, K.M., 2010, Role of the copper transporter, CTR1, in platinum-induced ototoxicity, J Neurosci, 30(28):9500-9509.

MUKHOPADHYAY, P., RAJESH, M., PAN, H., PATEL, V., MUKHOPADHYAY, B., BATKAI, S., GAO, B., HASKO, G., PACHER, P., 2010, Cannabinoid-2 receptor limits inflammation, oxidative/nitrosative stress, and cell death in nephropathy, Free Radic Biol Med, 48(3):457-467.

MUNRO, A.J., 1995, An overview of randomised controlled trials of adjuvant chemotherapy in head and neck cancer, Br J Cancer, 71(1):83-91.

NAKAI, Y., KONISHI, K., CHANG, K.C., OHASHI, K., MORISAKI, N., MINOWA, Y., MORIMOTO, A., 1982, Ototoxicity of the anticancer drug cisplatin. An experimental study, Acta Otolaryngol, 93(1-6):227-232.

OLGUN, Y., AKTAS, S., ALTUN, Z., KIRKIM, G., KIZMAZOGLU, D.C., ERCETIN, A.P., DEMIR, B., INCE, D., MUTAFOGLU, K., DEMIRAG, B., ELLIDOKUZ, H., OLGUN, N., GUNERI, E.A., 2016a, Analysis of genetic and non genetic risk factors for cisplatin ototoxicity in pediatric patients, Int J Pediatr Otorhinolaryngol, 90:64-69.

OLGUN, Y., ALTUN, Z., AKTAS, S., ERCETIN, P., KIRKIM, G., KIRAY, M., BAGRIYANIK, A., OZOGUL, C., SERBETCIOGLU, B., GUNERI, E.A., 2013, Molecular Mechanisms of Protective Effect of Resveratrol Against Cisplatinium Induced Ototoxicity, Journal of International Advanced Otology, 9(2):145-152.

OLGUN, Y., KıRKıM, G., ALTUN, Z., AKTAŞ, S., KOLATAN, E., KIRAY, M., BAĞRIYANIK, A., OLGUN, A., KIZMAZOĞLU, D.Ç., ÖZOĞUL, C., 2016b, Protective Effect of Korean Red Ginseng on Cisplatin Ototoxicity: Is It Effective Enough?, Journal of International Advanced Otology, 12(2). 
OLGUN, Y., KIRKIM, G., KOLATAN, E., KIRAY, M., BAGRIYANIK, A., OLGUN, A., KIZMAZOGLU, D.C., ELLIDOKUZ, H., SERBETCIOGLU, B., ALTUN, Z., AKTAS, S., YILMAZ, O., GUNERI, E.A., 2014, Friend or foe? Effect of oral resveratrol on cisplatin ototoxicity, Laryngoscope, 124(3):760-766.

PAULINO, A.C., SIMON, J.H., ZHEN, W., WEN, B.C., 2000, Long-term effects in children treated with radiotherapy for head and neck rhabdomyosarcoma, Int J Radiat Oncol Biol Phys, 48(5):1489-1495.

PEARSON, S.E., MEYER, A.C., ADAMS, G.L., ONDREY, F.G., 2006, Decreased hearing after combined modality therapy for head and neck cancer, Am J Otolaryngol, 27(2):7680.

PETERS, U., PREISLER-ADAMS, S., HEBEISEN, A., HAHN, M., SEIFERT, E., LANVERS, C., HEINECKE, A., HORST, J., JURGENS, H., LAMPRECHTDINNESEN, A., 2000, Glutathione S-transferase genetic polymorphisms and individual sensitivity to the ototoxic effect of cisplatin, Anticancer Drugs, 11(8):639-643.

PIGEOLET, E., CORBISIER, P., HOUBION, A., LAMBERT, D., MICHIELS, C., RAES, M., ZACHARY, M.D., REMACLE, J., 1990, Glutathione peroxidase, superoxide dismutase, and catalase inactivation by peroxides and oxygen derived free radicals, Mech Ageing Dev, 51(3):283-297.

PIGNON, J.P., BAUJAT, B., BOURHIS, J., 2005, [Individual patient data meta-analyses in head and neck carcinoma: what have we learnt?], Cancer Radiother, 9(1):31-36.

PIGNON, J.P., BOURHIS, J., DOMENGE, C., DESIGNE, L., 2000, Chemotherapy added to locoregional treatment for head and neck squamous-cell carcinoma: three meta-analyses of updated individual data. MACH-NC Collaborative Group. Meta-Analysis of Chemotherapy on Head and Neck Cancer, Lancet, 355(9208):949-955.

PIGNON, J.P., LE MAITRE, A., BOURHIS, J., 2007, Meta-Analyses of Chemotherapy in Head and Neck Cancer (MACH-NC): an update, Int J Radiat Oncol Biol Phys, 69 (2 Suppl): 112-114.

PLOWMAN, P.N., 2002, Post-radiation sensorineuronal hearing loss, Int J Radiat Oncol Biol Phys, 52(3):589-591.

RAMAN, C.S., LI, H., MARTASEK, P., SOUTHAN, G., MASTERS, B.S., POULOS, T.L., 2001, Crystal structure of nitric oxide synthase bound to nitro indazole reveals a novel inactivation mechanism, Biochemistry, 40(45):13448-13455.

RATHINAM, R., GHOSH, S., NEUMANN, W.L., JAMESDANIEL, S., 2015, Cisplatininduced apoptosis in auditory, renal, and neuronal cells is associated with nitration and downregulation of LMO4, Cell Death Discov, 1.

RAUSARIA, S., KAMADULSKI, A., RATH, N.P., BRYANT, L., CHEN, Z., SALVEMINI, D., NEUMANN, W.L., 2011, Manganese(III) complexes of bis(hydroxyphenyl)dipyrromethenes are potent orally active peroxynitrite scavengers, $\mathrm{J}$ Am Chem Soc, 133(12):4200-4203.

REN, T., NUTTALL, A.L., MILLER, J.M., 1997, ATP-induced cochlear blood flow changes involve the nitric oxide pathway, Hear Res, 112(1-2):87-94.

RIEDEMANN, L., LANVERS, C., DEUSTER, D., PETERS, U., BOOS, J., JURGENS, H., AM ZEHNHOFF-DINNESEN, A., 2008, Megalin genetic polymorphisms and individual sensitivity to the ototoxic effect of cisplatin, Pharmacogenomics J, 8(1):2328. 
ROSENBERG, B.H., CAVALIERI, L.F., 1965, Template deoxyribonucleic acid and the control of replication, Nature, 206(988):999-1001.

ROSS, R.A., SPENGLER, B.A., BIEDLER, J.L., 1983, Coordinate morphological and biochemical interconversion of human neuroblastoma cells, J Natl Cancer Inst, 71(4):741-747.

RYBAK, L.P., 2007, Mechanisms of cisplatin ototoxicity and progress in otoprotection, Current opinion in otolaryngology \& head and neck surgery, 15(5):364-369.

RYBAK, L.P., HUSAIN, K., MORRIS, C., WHITWORTH, C., SOMANI, S., 2000, Effect of protective agents against cisplatin ototoxicity, Am J Otol, 21(4):513-520.

RYBAK, L.P., MUKHERJEA, D., JAJOO, S., RAMKUMAR, V., 2009, Cisplatin ototoxicity and protection: clinical and experimental studies, Tohoku J Exp Med, 219(3):177-186.

RYBAK, L.P., WHITWORTH, C.A., MUKHERJEA, D., RAMKUMAR, V., 2007, Mechanisms of cisplatin-induced ototoxicity and prevention, Hear Res, 226(1-2):157167.

SAKAMOTO, M., KAGA, K., KAMIO, T., 2000, Extended high-frequency ototoxicity induced by the first administration of cisplatin, Otolaryngol Head Neck Surg, 122(6):828-833.

SANCHEZ-GONZALEZ, P.D., LOPEZ-HERNANDEZ, F.J., PEREZ-BARRIOCANAL, F., MORALES, A.I., LOPEZ-NOVOA, J.M., 2011, Quercetin reduces cisplatin nephrotoxicity in rats without compromising its anti-tumour activity, Nephrol Dial Transplant, 26(11):3484-3495.

SANTABARBARA, G., MAIONE, P., ROSSI, A., GRIDELLI, C., 2016, Pharmacotherapeutic options for treating adverse effects of Cisplatin chemotherapy, Expert opinion on pharmacotherapy, 17(4):561-570.

SCHACHT, J., TALASKA, A.E., RYBAK, L.P., 2012, Cisplatin and aminoglycoside antibiotics: hearing loss and its prevention, Anat Rec (Hoboken), 295(11):1837-1850.

SCHULTZ, C., GOFFI-GOMEZ, M.V., PECORA LIBERMAN, P.H., PELLIZZON, A.C., CARVALHO, A.L., 2010, Hearing loss and complaint in patients with head and neck cancer treated with radiotherapy, Arch Otolaryngol Head Neck Surg, 136(11):10651069.

SLUYTER, S., KLIS, S.F., DE GROOT, J.C., SMOORENBURG, G.F., 2003, Alterations in the stria vascularis in relation to cisplatin ototoxicity and recovery, Hear Res, 185(12):49-56.

SMOORENBURG, G.F., DE GROOT, J.C., HAMERS, F.P., KLIS, S.F., 1999, Protection and spontaneous recovery from cisplatin-induced hearing loss, Ann N Y Acad Sci, 884:192210.

SOMANI, S., HUSAIN, K., JAGANNATHAN, R., RYBAK, L., 2001, Amelioration of cisplatin-induced oto-and nephrotoxicity by protective agents, Ann Neurosci, 8:101113.

SUM, E.Y., PENG, B., YU, X., CHEN, J., BYRNE, J., LINDEMAN, G.J., VISVADER, J.E., 2002, The LIM domain protein LMO4 interacts with the cofactor CtIP and the tumor suppressor BRCA1 and inhibits BRCA1 activity, J Biol Chem, 277(10):7849-7856.

TAKUMIDA, M., ANNIKO, M., 2001, Nitric oxide in guinea pig vestibular sensory cells following gentamicin exposure in vitro, Acta Otolaryngol, 121(3):346-350. 
TERANISHI, M.A., NAKASHIMA, T., 2003, Effects of trolox, locally applied on round windows, on cisplatin-induced ototoxicity in guinea pigs, Int $J$ Pediatr Otorhinolaryngol, 67(2):133-139.

TIAN, Y., WANG, N., LU, Z., 2010, Repression of Lim only protein 4-activated transcription inhibits proliferation and induces apoptosis of normal mammary epithelial cells and breast cancer cells, Clin Exp Metastasis, 27(7):455-463.

TUFEKCI, O., GUNES, D., OZOGUL, C., KOLATAN, E., ALTUN, Z., YILMAZ, O., AKTAS, S., ERBAYRAKTAR, Z., KIRKIM, G., MUTAFOGLU, K., SOYLU, A., SERBETCIOGLU, B., GUNERI, E.A., OLGUN, N., 2009, Evaluation of the effect of acetyl L-carnitine on experimental cisplatin nephrotoxicity, Chemotherapy, 55(6):451459.

VAN DEN BERG, J., BEIJNEN, J., BALM, A., SCHELLENS, J., 2006, Future opportunities in preventing cisplatin induced ototoxicity, Cancer treatment reviews, 32(5):390-397.

VAN RUIJVEN, M.W., DE GROOT, J.C., KLIS, S.F., SMOORENBURG, G.F., 2005, The cochlear targets of cisplatin: an electrophysiological and morphological time-sequence study, Hear Res, 205(1-2):241-248.

VAN RUIJVEN, M.W., DE GROOT, J.C., SMOORENBURG, G.F., 2004, Time sequence of degeneration pattern in the guinea pig cochlea during cisplatin administration. A quantitative histological study, Hear Res, 197(1-2):44-54.

WAISSBLUTH, S., DANIEL, S.J., 2013, Cisplatin-induced ototoxicity: transporters playing a role in cisplatin toxicity, Hear Res, 299:37-45.

WANG, L.F., KUO, W.R., HO, K.Y., LEE, K.W., LIN, C.S., 2004, A long-term study on hearing status in patients with nasopharyngeal carcinoma after radiotherapy, Otol Neurotol, 25(2):168-173.

WANG, N., LIN, K.K., LU, Z., LAM, K.S., NEWTON, R., XU, X., YU, Z., GILL, G.N., ANDERSEN, B., 2007, The LIM-only factor LMO4 regulates expression of the BMP7 gene through an HDAC2-dependent mechanism, and controls cell proliferation and apoptosis of mammary epithelial cells, Oncogene, 26(44):6431-6441.

WATANABE, K., TOMIYAMA, S., JINNOUCHI, K., YAGI, T., 2001, Apoptosis in the hydropic cochlea of guinea pigs following immune reaction of the endolymphatic sac: immunohistochemical analysis, Eur Arch Otorhinolaryngol, 258(6):296-299.

WATANABE, K.I., HESS, A., BLOCH, W., MICHEL, O., 2000, Nitric oxide synthase inhibitor suppresses the ototoxic side effect of cisplatin in guinea pigs, Anticancer Drugs, 11(5):401-406.

ZDANSKI, C.J., CARRASCO, V., JOHNSON, K., PRAZMA, J., PILLSBURY, H.C., 1998, Inhibition of nitric oxide synthase causes elevation of hearing thresholds, Otolaryngol Head Neck Surg, 119(3):159-163.

ZHANG, Y., LIN, Z.A., PAN, J.J., ZHENG, Z., YANG, L., LIN, S.J., ZHENG, F., 2009, [Concurrent control study of different radiotherapy for primary nasopharyngeal carcinoma: intensity-modulated radiotherapy versus conventional radiotherapy], Ai Zheng, 28(11):1143-1148.

ZUUR, C.L., SIMIS, Y.J., LAMERS, E.A., HART, A.A., DRESCHLER, W.A., BALM, A.J., RASCH, C.R., 2009, Risk factors for hearing loss in patients treated with intensitymodulated radiotherapy for head-and-neck tumors, Int J Radiat Oncol Biol Phys, 74(2):490-496. 